\title{
Shikasta and The Marriages: New Directions in Doris Lessing's Fiction
}

\author{
Dr. Erinda Papa \\ Fan S. Noli University, Korce, Albania \\ erindapapa@yahoo.com \\ Dr. Benita Stavre \\ Fan S. Noli University, Korce, Albania \\ b.stavre@gmail.com
}

DOI:10.5901/mjss.2014.v5n19p40

\begin{abstract}
Regardless of the form that she gave to her science - fiction, Doris Lessing remains stable in the issues and concerns surrounding these novels. Lessing's many ideas underscoring the Canopus series make it as prosperous as the previous works of this writer. The awareness of the individual is a topic that gives continuity to Lessing's work and feeds as well as promotes the tension and energy work linking external and internal phenomena symbolically. This theme is embodied in this series showing that Lessing actually underwent an extraordinary twist with the Canopus series, but thoroughly analyzed the same idea infiltrating into other territories. Observing sustainability marks the central object of this paper, along with some knowledge of science - fiction novels. By analyzing the first two novels of the series Canopus in Argos: Archives, we aim to show that that $D$. Lessing uses science - fiction genre to give a new look to her old concerns, and to lay eyes on completely new problems. Essential for the penetration of ideas, are the formal choices made in the Canopus series. The series draws attention to the separate traditional elements of history, science - fiction, educational Sufi tales, as well as the cohesion that makes fantasy, allegory, autobiography and satire. During the analysis of the first two novels in the Canopus series, we aim to argue that through a "hodgepodge" of events full of life, Doris Lessing appears to be confident, positive, pleasant and coherent.
\end{abstract}

Key words: Doris Lessing, Science-fiction, Canopus in Argos, Responsibility, Balance, Happiness

\section{Introduction}

The fiction work completed by Doris Lessing can be divided into three different phases or categories which are the communist theme, the psychological theme and the science fiction or Sufi theme. Lessing started out with the communist theme where she thoroughly wrote about various significant social issues from 1944 to 1956 while returning to this theme in her books The Good terrorist which was written in 1985. The psychological phase of Lessing's fictional writing covered a period of thirteen years from 1956 to 1969 where she touched on various psychological issues. The third phase of Lessing's fictional work was based on science fiction where hints of Sufism could also be seen in her writing. The science fiction phase encompasses a period of thirteen years from 1973 to 1989 and is entirely based on her science fiction novel series entitled Canopus in Argos: The Archives. The series includes five science fiction novels which were written in the period of 1973-1989.

The science fiction series has a lot of Sufi influence of the writer and Lessing preferred to regard the series as space fiction rather than science fiction. Although Lessing invested a lot of time and efforts in her Canopus in Argos series it was not well received by many literary circles and critics. Lessing terms the Canopus series as the most important and favorite among all of her literary works. Lessing has described the efforts and actions of a technologically advanced and evolved intergalactic race in increasing the evolutionary rate of other planets such as Earth. Several other writers have followed the same theme and style in their science fiction work such as the series of Progressor and Uplift. Mrs. Lessing on the other hand has utilized Sufi concepts and themes in her science fiction writing due to her influence towards Sufism which was introduced to her by Idries Shah who was a teacher and good friend of Doris Lessing (Galin, 1997).

The approach implemented by the author in her science fiction series is similar to the approach utilized by G. I. Gurdjieffin his book All and Everything in the early 20th century. Some other attempts of Doris Lessing at focusing on science fiction 
or space fiction also use a somewhat similar theme such as the Memoirs of a Survivor which was published in 1974 and the Briefing for a Descent into Hell which was published earlier in 1971.Although, Doris Lessing's earlier work focused on the communist theme but after mid 1960's when she was influenced by Sufism she realized that matters and issues relevant to spiritual existence and interaction had been ignored in Communism and Marxism she was quite disappointed and that is why she turned to the Sufism theme. This paper analyzes and explains the themes and styles in science fiction works of Doris Lessing. As her science fiction work is mainly based on the Canopus in Argos series the paper will analyze the themes, styles and plots of the novels in these series to examine the overall approach applied by Mrs. Lessing in her science fiction work.

\section{Canopus in Argos: Archives}

The Canopus in Argos: Archives is a series of five science fiction or as termed by the Nobel Prize winning author space fiction novels which depicts various societies and planets which are at different phases of development or evolution over a significant duration of time. The primary emphasis in the series is laid on the support provided by more advanced societies, races or species to less advanced or evolved species in accelerating the rate of evolution. The time frame of all of the novels is the same futuristic period but the novels are not based on a continuous and single story line as it is usually the case with many novels in a series. The events, themes and actions portrayed in the novels are quite unrelated except The Sirian Experiments and Shikasta both of which focus on Earth and its accelerated evolution in the view of Sirians and Canopeans respectively.

According to the author, when she started writing Shikasta, the first novel of the series she had not idea and no intention of writing a whole series and it was meant to be a single stand alone book and not part of a series. Albeit, as she progressed in writing and the fictional worlds, galaxies and universe started to expand she realized that far more ideas had developed than the ones which could be covered in a single book and that is how five whole books in a single series ended up being written (Lessing, 1979, p. 8).Although the first two books of the series, Shikasta and The Marriages between Zones Three, Four and Five, were not well received by the critics, the good response by general readers convinced the writer into writing the next novel in the series which was The Sirian Experiments (Lessing, Preface. The Sirian Experiments, 1980, p.11).

Lessing implies that she has written the whole series to enable readers to understand possibilities and ideas with respect to our world and society through fascinating stories about intergalactic worlds in a futuristic setting. The theme of the whole Canopus in Argos sequences can be categorized as that of soft or social science fiction or as the author puts it social fiction as it is not based on detailed portrayal of scientific or futuristic technology unlike other science fiction novels but rather it lays emphasis on the interaction of the characters or worlds with each other and the socio-cultural issues of those worlds or societies. Starting her science fiction series meant a significant shift from her primary domain as she started being influenced by the ideologies of Sufism and mysticism, especially those which were introduced to her by her friend and teacher Idries Shah. Apart from this series of novels, she was so influenced by Sufi themes that she wrote numerous essays on Sufism which were published as a collection entitled Time Bites in 2004 (Nobelprize.org, 2007).

\section{Novel 1: Shikasta}

The first novel in the series of Canopus in Argos is Shikasta: Re, Colonised Planet 5 which is often referred to in its short form only as Shikasta. The title of the novel is based on the name of the planet featured in the novel which is also Shakasta. The subtitles on the cover of the book read Personal, psychological, historical documents relating to visits by JOHOR (George Sherban) Emissary (Grade 9) 87thof the Period of the Last Days.

Shikasta basically depicts a world which is synonymous to Earth and portrays the history of this world from early times to the future history of the world. The novel covers this history under the rule or influence of three different extraterrestrial empires which are the Canopus, Sirius and their common enemies the Puttiora. The novel basically encompasses a series of several reports presented by emissaries of Canopus to Shikasta, which document the pre-history of the planet, the deterioration of the planet which leads to the destruction century based on the 20th century of Earth and the end of the world of Apocalypse in the form of the third world war. The historical aspects covered in the novel are quite similar to the historical events of Earth and that is why many reviewers and readers relate the planet Shikasta to our green planet.

The planet Shikasta is illustrated through or based on the depictions of the historical events in the Old Testament of the bible but also quite heavily draws on Sufi themes of mysticism and spiritualism as Lessing had developed quite an interest in Sufism her work was thus heavily influenced by it. This influence of Sufism was one of the primary reasons for Lessing's 
shift from writing on realism to writing in the science fiction genre. This shift from realism disillusioned a large number of her readers and while many critics, readers and reviewers were impressed by Lessing's efforts several others heavily criticized the book implying that the novel was very deficient in vision and scope as it presented a very negative prospect of Earth in reflection of Shikastas the fate of the Shikastan people was dependent on the decisions and actions of inter galactic empires such as Canopus and there was no free will among the inhabitants of Shikasta. The story of planet Shikasta in the first book lays the foundation for the whole Canopus in Argos series where the first novel depicts the story of Shikasta from the viewpoint of Canopeans while the third novel The Sirian Experiments illustrates the story of Shikasta from the view point of Sirians which is another advanced galactic race.

The plot of the novel can be related directly to the historical events of Earth as depicted by the Bible but is also quite influenced by notions of preaching, righteousness, harmony and spiritual development which are primary aspects of spirituality and mysticism found in the Sufi ideology. The book portrays a compassionate terrestrial empire by the name of Canopus which is located in the Argo Navis constellation and inhabits a very young planet named Rohanda (the fruitful) which shows good potential with respect to development. This part of the story is quite similar to the colonial expansion which took place in the early days where humans colonized new lands and sought harmony with others. The Canopeans colonize the planet with blossoming species or humanoids and speed up their rate of evolution and this is done mainly to depict the entire history in the novel otherwise the entire history similar to that of the entire history of Earth would require books upon books. When the inhabitants of Rohanda have evolved enough and are ready a specific mechanism referred to as a lock is implemented on the planet Rohanda which directly connects the planet to the strength and harmony of the whole Canopus Empire through the astral currents of Rohanda.

Apart from Canopeans, two other galactic empires namely the Sirius and Puttiora also ensure that some sort of existence is established on the planet. The Sirius Empire is an ally of the Canops Empire while Puttoria is the common enemy of both Canopus and Sirius. The activities and presence of the Sirians are limited to the southern continents in the prehistoric phases of Rohanda where genetic experiments are conducted and these experiments are comprehensively covered in the third book of the series which is The Sirian Experiments. On the other hand the Shammat of Puttiora though have a presence on the planet they remain inactive simply waiting for the right time and opportunity to attack and seize the moment. This clearly follows a theme of Earth where different parts of a single country or continent are colonized and influenced by various empires which was quite prevalent in the colonial age of our world.

The humanoids inhabiting planet Rohanda thrive and flourish under the influence of the Canopus Empire which has stimulated a climate of accelerated evolution, development, co-existence, tolerance and brotherhood. Apart from accelerated evolution, heavy influence of spirituality in Sufism can be seen in the writings of the author which also teaches tolerance, brotherhood and co-existence. All is going well for Rohanda until the lock or link with the Canopeans breaks and all the resources from Canopus are removed including a substance referred to as SWOF by the Canopeans which simply stands for a Substance of We Feeling. This substance keeps all the values of the inhabitants intact where they have a sense of collective prosperity rather than individual development.

As the inhabitants are deprived of SOWF they fall prey to a degenerative disease and they start prioritizing their personal goals instead of the collective good (Gore, 1979). Again this notion has been adapted from Sufism where the collective goals are kept over the goals of the individual. The Shammat of Puttoria identify the opportunity and start discouraging the influence of the Canopus Empire by exploiting the disturbance caused by the breaking of the lock and infest the inhabitants of Rohanda with their own evil ideologies. The Canopeans left with no choice change the name of the planet to Shikasta which literally means broken or stricken much to their disliking as the conflict increases and the Rohandanians grow more and more greedy. The author later relates Rohanda or Shikasta to a symbolic Earth in a parallel world with its own history and heritage (Gore, 1979).

The Cannopian Empire sends emissaries to Shikastain order to save the inhabitants and Johor is one of the emissaries who is sent to the planet who transforms himself into a native and starts to spot people who have not relapsed significantly and are open to the corrective teachings he provides. This is much similar to prophets who have been sent to Earth as depicted in the Bible such as Noah, Moses and Jesus. Once some of the natives are converted back or corrected they are sent to other natives to preach and spread the teachings and soon small and confined communities start returning to the earlier state much like the rehabilitation of humans through biblical preachers and prophets. As there is no SOWF from Cannopus, the natives degenerate at a very rapid rate even when the emissaries teach and preach the natives. In the late 20th century Shikasta falls to its doom and the Apocalypse or the third world war breaks out. Johor is returned to the planet and incarnated to Shikasta via Zone 6 as a Shikastan named George Sherban. As George Sherban grows up he establishes 
contact with other Canopean emissaries in disguise and continues his attempt to help the Shikastans but due to several problems the natives keep degenerating.

George Sherban along with other emissaries migrate with a few Shikastan followers just before world war three starts so they can escape the nuclear disaster. This style or theme follows the historical and biblical events of the Exodus where Moses takes his followers to a safe place to safeguard them from coming danger and that of Noah where he takes his followers to safety to avoid world destruction. The war then wipes out almost all of the population of Shikasta and only the people who relocated with Sherban and other emissaries are left to repopulate the planet. The Shammat of Puttoria who played a major role in the destruction of the Shikastans withdraw themselves from Shikasta and the remaining survivors with the help of the Canopean emissaries rebuild their planet and realign with the Canopus and the lock and link with the Canopus Empire is reestablished and SOWF is restored.

The name of the first book in the Canopus in Argos series is Shikasta which is based primarily on the Persian word Shekasteh which means stricken or broken. As Lessing was born in Persia which is now known as Iran, she named the book after a word derived from the Persian language. Although Lessing does not express or state anywhere in the book or otherwise that the planet Shikasta in the book is based on Earth but many readers, reviewers and critics are of the view that as the history of both Shikasta and Earth are quite similar, Shikasta is in fact Earth as perceived by the Canopus Empire. Also, these critics also believe that Shikasta is Earth as many of the geographical locations found in book in the reports written by the emissaries resemble countries and locations on Earth. Alternatively, many other reviewers believe that Shikasta is not Earth but a planet in a parallel universe which is quite similar to Earth but the histories of both planets differentiate at different points in time.

Many critics regard Shikasta as an antinovel mainly because it steers clear of the standard principles or conventions of a traditional novel and the author portrays the events of the Planet Shikasta as seen by the emissaries of Canopus. The author has set the novel as a case study to be used by students of first year with respect to the Colonial rule of Canopus and the times of Shikasta as a part of that rule. The case study is provided in the form of various documents including journals and letters prepared by specific inhabitants of Shikasta, excerpts from the History of Shikasta Canopean record and the reports written by emissaries of Canopus sent to Shikasta from time to time. The novel portrays the Canopeans as immortals who examine the history of the planet from its early stages of evolution when it bears the name of Rohanda all the way to the century of destruction when the planet has been renamed to Shikasta. It is important to note that this history is closely tied and in sync with the history of planet Earth and follows significant events as they happened in Earth. The apocalypse depicted in the novel can be regarded as the futuristic events that may take place on Earth when the outside forces such as the Chinese occupy several parts of Europe and this is portrayed in the novel by the occupation of Shikasta by the Shammat of Puttoria and the third world war breaks out which renders the planet almost uninhabited and the author claims that it is a true history of the planet (Frick, 1988).

The primary themes in the novel have been derived from the Old Testament of the Bible, several themes and styles of Sufism and some themes of Gnosticism which is a belief system which implies that the materialist world should be ignored to embrace the spiritual world. Additionally, there are also several hints of themes adapted from Judeo-Christian beliefs and the author herself accepts in the preface of the book that the roots of the novel are embedded in the Old Testament of the Bible. Lessing mentions the Substance of We Feeling as a source of harmony to Shikasta which flows from Canopus to the planet through the lock and this SOWF is basically a type of spiritual power or nourishment which is adapted from Sufism as well. Many reviewers point out the similarities between the novel and the Bible where the Canopeans and their emissaries can be linked to God and the angles and prophets which were sent from time to time on Earth as mentioned in the Bible. It is also noteworthy that the environment of the planet is closely related to the religious space or environment of Sufism, while the efforts of the Canopeans to revive the Shikastans and confront the ways of the Shammat are basically a war between good and evil as portrayed in many religious beliefs while the degenerative disease that engulfs the planet is related to the original sin referred to in the Old Testament. Some reviewers have also linked the novel to Baha'ism and imply that the Apocalypse and Johor as the savior of the planet are linked to the arrival of a prophet on Earth for the renewal of faith.

\section{Novel 2: The Marriages between Zones Three, Four and Five}

Doris Lessing wrote five novels in her science fiction series Canopus in Argos: Archives between the period of 1979 to 1983 and the first book of the series, Shikasta, introduced a lot of concepts, themes and notions for the overall series and laid the foundation for the next four books to be written. All of the five books do not follow a single story line but are 
connected with one another in some way especially through the Canopus benevolent colony situated in the Argos galactic system. The second book in the series is the Marriages between Zones Three, Four and Five (as narrated by the Chroniclers of Zone Three). Lessing introduced six zones in the first novel of the series Shikasta and in this novel three of these metaphysical zones are depicted where marriages take place between the rulers of Zone Three, Zone Four and Zone 5. Zone three is portrayed as an egalitarian and matriarchal zone while Zone Four is depicted as a militaristic and patriarchal zone and the Zone Five is illustrated as the barbaric or primitive and tribal zone. The novel depicts the story of these marriages along with related events from the perspective of chroniclers of Zone Three who record all these events in chronicles. The entire novel is based on the notion of conflicts and barriers that exist between the genders and their viewpoint of the world along with the method of government and running a society. This is the primary reason why many reviewers and critic cite the novel as part of the feminist science fiction genre even when Lessing implies that it is space fiction. The story portrayed in the novel was quite interesting and it is because of this fact that the novel was also adapted by Philip Glass as an opera.

As Lessing was quite impressed and interested in Sufism before writing the series, many themes of Sufism are evident throughout the novels of the series. Even in the second novel each of the zones depicted by the author are related to the various levels of consciousness and enlightenment in Sufism where the hierarchy of enlightenment starts from the lowest level and reaches the highest level of enlightenment through a specific process. Albeit, the author faced a lot of criticism for shifting from standard fiction to science fiction with religious and Sufi themes and many critics termed her as going religious, the second novel of the series received a very good response from a majority of reviewers and a lot of critics also termed the second novel in the series as her best attempt in portraying gender conflict.

Lessing introduced the six metaphysical zones in Shikasta, but the main emphasis was only on the last zone which was Zone six in which the planet Rohanda or Shikasta was located. The first novel described Shikasta as being surrounded by six different layers of metaphysical zones and each of these six zones represented levels of spirituality. The spiritual level increases with each zone with zone six being the lowest and zone 1 being the highest. The first novel only dealt with the most impure zone six which was the immediate environment of planet Rohanda or Shikasta and served as a purgatory or intermediate zone where inhabitants were punished and awaiting revival from a divine source such as an angel or prophet (Glover, 2007).

In the second novel, on the other hand, the author expands her scope from zone six to higher zones and portrays each zone as self sustaining and autonomous countries or societies with each one having its own environment, government system, norms and stage of evolution and development. This notion is closely linked to the enlightenment stages in Sufism where a being is more enlightened as it crosses each phase or stage of the enlightenment hierarchy. This is evident from the fact that zone three is portrayed as the most evolved and zone five depicted as primitive and least evolved or developed. Each of the zones in the hierarchical structure border with the next zone in line while the geography of each zone also changes as they increase with respect to topography and mountains (Glover, 2007). The inhabitants of each zone can cross over to the other zone through the boundaries or frontiers but crossing from one zone to another is avoided mainly due to the negative effects it may have on the person's health and anyone wishing to go from one zone to another is provided with shields that protect the person from the adverse environment of the other zone (Waterman, 2002). This theme deviates from the themes of Sufism and Mysticism as traditionally a person cannot enter a state of higher enlightenment on will and cross from one state into another as he/she wills.

In order to evaluate the themes in the second novel of the series it is important to analyze the context and background in which it was written. Lessing had earlier written the first novel by the name of Shikasta which indicated a significant shift in her writing from traditional fiction to science fiction based on Sufi and Mystic themes. This shift was mainly due to the interest she had developed by reading Idries Shah's book entitled The Sufis and she herself claims that it was one of the most surprising books she had ever readand that the book had changed her life and perception about reality, enlightenment and spirituality (The Daily Telegraph, 1996). Lessing was so inspired by Sufi concepts, notions and themes that she embedded them in Shikasta which was to be a complete book in itself and a series was not intended. On the other hand, when she started writing the first book of the series she realized that the ideas she was able to generate could not be covered in a single book so she moved on to write four more books and make up an entire series. The Sufi concepts and themes introduced in Shikasta were reinforced in the second book of the series. Moreover, the book was also significantly based on feminist and gender conflict issues and that is why the second novel was also termed by many as feminist science fiction. Lessing implied that the second book was one of her most impressing works and that she had reached a level she could not imagine herself and suggested that she could never write such a book again (Sperlinger, 2012). 
The story of the second novels is rooted in the relationships in the form of ordained marriages between the rulers of Zone three, Zone four and Zone five. The providers who are not identified and implied as being invisible to the inhabitants of all the three zones order the queen of Zone three Al-Ith to marry the king of Zone four Ben Ata. Zone three is depicted as a peaceful and matriarchal zone while zone four is portrayed as a repressed and heavily militarized zone. Both of the rulers are quite reluctant in marrying each other mainly due to the fact that Ben Ata feels that his wife should not be a powerful queen who could affect his military ambitions and disturb the male dominance in his zone while Al-lth feels that she should not marry a barbaric king who is the ruler of a male dominated zone. Nonetheless, both of the rulers have to marry as per the orders of the providers and they eventually get married. Both of the rulers feel very strange as Al-Ith is not used to men who are charged with male dominance while Ben Ata is not accustomed to the company of females who cannot be controlled. Eventually both of them grow fond of each other as time passes but at the same time are quite amazed and shocked at the governmental systems is their respective zones. Ben Ata finds it very shocking that Zone three does not have an army at all while Al-Ith is astounded by the fact that a major portion of Zone four's wealth goes into the development of the army while the remaining population of the zone lives in very poor conditions. This part of the plot resembles the autocratic and democratic systems of governments in the real world where usually in a democracy a lot of a country's wealth is spent on development and wellbeing of the citizens while a lot of a country's wealth is spent in developing and improving armies in a dictatorship.

Sometime after the marriage between Ben Ata and Al-Ith a son is born who is named Arusi and the author has derived this name from the name given to babies in various African cultures including Zimbabwe where Lessing spent some of her years as a child and the name basically means the sun or bright light. Arusi is the heir of Zones three and four and under the leadership of a woman named Dabeeb some women of Zone four help Al-lth during the time of birth and afterwards. As these women belong to the male dominated society of Zone four they enjoy the company of the queen of Zone three which is a female dominated society. The providers then command that Al-Ith return to her zone without accompanying the new born son and Ben Ata is commanded to marry the queen of Zone five named Vahshi. This name again is derived from the Persian influence which means barbarian to imply the barbarian image of Zone five. As the rulers of Zone three and four have grown fond of each other they are overwhelmed with sadness but yet again they have no choice but to follow orders.

Al-Ith returns to her zone only to find herself in a predicament as her sister Murtiis now ruling the zone as a queen and AlIth is exiled to the bordering area of Zone two where she finds Zone two to be very attractive and tries to cross over to that zone but is informed that her time for entering Zone two has not come. Meanwhile, Ben Ata gets reluctantly married to Vahshiwho then convinces her to change the government administrative procedures as he himself has changed quite a lot due to his marriage with Al-Ith. Arusi, the son of Ben Ata and Al-Ith then travels with Dabeeb and the other women to Zone three to meet his mother and when the crossover to Zone three they are quite amazed by the position in which Al-Ith is. Ben Ata and Al-Ith are wary of this crossover as it has not been approved by the providers. On the other hand the local population of Zone three is also quite fearful of the foreign presence of inhabitants from Zone four.

The providers then command Ben Ata to crossover to Zone three and meet Al-Ith but he is quite amazed to see some young people blocking his way with temporary weapons. He returns again with an army from Zone four and does not face any opposition on entering Zone three. He meets with Al-Ith and informs her about the changes which have been made in Zone four and also how he managed to bring a change in Zone five by marrying the queen Vahshi. Some days later Al-Ith crosses over to Zone two not to return but the changes and developments which have been made in the three zones due to the marriages of the rulers of these zones are very evidence of the fact how sharing of knowledge and experience between the genders can create a difference. The primary theme which can be evidently identified throughout the novel is the resolution of gender conflicts through various means while a feminist ideology is also present when Lessing describes Zone three in detail with significant hints of Sufism and mysticism throughout the novel.

The novel portrays the marriages and relevant events through the eyes or perspectives of the chroniclers of the third zone which is primarily a matriarchal and female dominated zone and thus the novel can be included in the realm of feminist novels but based on science fiction which may render it as a feminist science fiction piece of literature. Albeit the entire series falls under the category of soft science fiction or as Lessing refers to it as space fiction as there is not much dependence on the advancements of technology and science but there is a focus on societies, the second novel clearly breaks from the main theme and goes into a feminist paradigm (Feminist Science Fiction, 2010). Additionally, the novel is different from its counterpart in the Canopus in Argos series as it is written like a story or tale which is set outside of the space/time continuums of the rest of the novels in the series. 
The story follows marriages between rulers of three different zones where one zone is barbaric and primitive, the other zone is patriarchal and militaristic and the third zone is equalitarian and matriarchal. These three types of zones basically imply the inherent nature of people and the differences between the genders and sexes with respect to various issues and how these issues are resolved through knowledge and information sharing and understanding. Lessing implies through this novel that universal harmony can be achieved when genders set aside their differences and work together to accomplish common goals. The differences in zones are related to the differences in levels of enlightenment in Sufism and Lessing implies that a new level of enlightenment can be reached through working positively and adhering to the best principles without considering the division between genders (Sheets, 2007).

The two marriages were commanded by the providers who have not been identified in this novel but many critics suggest that these providers are the Canopeans who were identified in the first novel of the series Shikasta. Lessing still keeps the notion of a spiritual being in the second novel who controls the live of humans and lack of free will but in the second novel she iterates the fact that if humans are nudged in the right direction they can bring about significant changes and this is implied by the reforms made by Al-Ith, Ben Ata and Vahshi in their respective zones (Shinn, 1986). On the other hand many critics imply that albeit Zone three can be seen as a feminist ideological society but Lessing implies that it is not an ideal society as well from the perspectives of the chroniclers who indicate issues present in the society due to stagnation. The reaction of Al-Ith when she returns to her own zone also implies that Zone three is not in fact an ideal society but there is room for improvements. The six zones as illustrated by Lessing in the novel are parallels to the various levels enlightenment and consciousness in Sufism and mysticism. The characters of Al-Ith and Ben Ata are both able to experience different levels of enlightenment through their marriage and when they cross over to the other zones. All in all the second novel is based on the feminist theme along with the themes adopted from the enlightenment levels of Sufism.

\section{Conclusion}

Regardless of the form that she gave to her science - fiction, Doris Lessing remains stable in the issues and concerns surrounding these novels. One of the most significant problems that arise with the Canopus series as suggested through the analysis of the first two novels of the series is related to the obligations and responsibilities of the artist. The idea of the writer as to the role and responsibilities of the artist, aligned with the myth of Sisyphus, takes place in this series. The role of the artist remains extraordinary as long as he keeps alive truth, love, reason, and beauty in human relationships. Lessing states that the extraordinary power of art should be directed to good purposes in three main directions: practical, ethical and spiritual. In all the practical problems that arise within D. Lessing's science-fiction, art functions as an important tool for solving them. In this regard, first he conveys the necessary information. Such is the case when the of Shikasta come to know through the songs sang about the departure of the giants in the first novel.

Lessing's many ideas underscoring the Canopus series make it as prosperous as the previous works of this writer. Roberta Rubenstein noted that "the awareness of the individual" is a topic that gives continuity to Lessing's work and feeds and promotes "the tension and energy work" linking "external and internal phenomena symbolically." (Rubenstein, 1979) This theme is embodied in this series showing that Lessing actually underwent an extraordinary twist with the Canopus series, but thoroughly analyzed the same idea infiltrating into other territories. Observing sustainability marks the central object of this paper, along with some knowledge of science - fiction novels. By analyzing the first two novels of the series Canopus in Argos: Archives, we aim to show that that D. Lessing uses science - fiction genre to give a new look to her old concerns, and to lay eyes on completely new problems. Essential for the penetration of ideas, are the formal choices made in the Canopus series. The series draws attention to the separate traditional elements of history, science - fiction, educational Sufi tales, as well as the cohesion that makes fantasy, allegory, autobiography and satire. During the analysis of the first two novels in the Canopus series, we tried to argue that through "hodgepodge" of events full of life Doris Lessing appears to be confident, positive, pleasant and coherent.

\section{Bibliography}

Alter, R. (1981). Doris Lessing in the Visionary Mode. The Newyork Times.

Edensor, T. (2002). National Identity, Popular Culture and Everyday Life. Oxford, New York: Berg Publishers.

Feminist Science Fiction. (2010, August 7). Research \& Literary Criticism. Retrieved May 15, 2013, from Feminist Science Fiction, Fantasy and Utopia: http://www.feministsf.org/crit/critrz.html 
Foucault, M. (1979). Discipline and punish: the birth of the prison. Vintage Books.

Frick, T. (1988). Doris Lessing, The Art of Fiction No. 102. Retrieved May 14, 2013, from The Paris Review: http://www.theparisreview.org/interviews/2537/the-art-of-fiction-no-102-doris-lessing

Galin, M. (1997). Sufism in the Novels of Doris Lessing. New York: State University of New York.

Gay, P. D., Evans, J., \& Redman, P. (2000). Identity: a reader. SAGE Publications in association with The Open University. Glover, J. (2007). Sufism and jihad in modern Senegal: the Murid order. Rochester, NY: University of Rochester Press.

Gore, V. (1979, October 20). Paradise Regained. Retrieved May 14, 2013, from The New York Review of Books: http://www.nybooks.com/articles/archives/1979/dec/20/paradise-regained/?pagination=false

Gray, P. (1979). Visit to Small Planet. Time.

Gray, P. (1980). More Lessing. Time.

Gray, P. (1981). Soul Mates. Time.

Hazelton, L. (2008). Doris Lessing on Feminism, Communism and 'Space Fiction'. University of Valencia .

Lehmann-Haupt, C. (1982, January 29). Books of the Times; Books Of The Times. Retrieved May 15, 2013, from The New York Times: Books: http://www.nytimes.com/1982/01/29/books/books-of-the-times-books-of-the-times.html

Leonard, J. (1981). Books of the Times: The Sirian Experiments. The Newyork Times.

Lessing, D. (1979). Some Remarks. London: Shikasta.

Lessing, D. (1980). Preface. The Sirian Experiments. London: Flamingo.

Lessing, D. (1980). The Sirian Experiments: Canopus in Argos: Archives. London: Granada.

Lessing, D. (1994(a)). The Sirian Experinment - Remarks .

Lessings, D. (1994b). The Sirians Experiment- Remarks .

Nobelprize.org. (2007). Doris Lessing: Biobibliographical Notes. Retrieved May 14, 2013, from Nobelprize.org: http://www.nobelprize.org/nobel prizes/literature/laureates/2007/bio-bibl.html

Rubenstein, R. (1979), The Novelistic Vision of Doris Lessing: Breaking the Forms of Consciousness, Urbana, Chicago, London: University of Illinois Press.

Sheets, D. E. (2007, November 4). Doris Lessing, Nobel Laureate, and the XX/YY Axis. Retrieved May 15, 2013, from Literary Gulag: https://ideals.illinois.edu/bitstream/handle/2142/3467/DorisLessing.htm

Shinn, T. J. (1986). Worlds within women: myth and mythmaking in fantastic literature by women. Westport: Greenwood Publishing Group.

Sperlinger, T. (2012, April 17). Five Doris Lessing Books to Read (Even If You Didn't Like The Golden Notebook). Retrieved May 15, 2013, from Huff Post Culture: http://www.huffingtonpost.co.uk/tom-sperlinger/5-doris-lessing-books-to_b_1423662.html

Stuart, H., \& Du, G. P. (1996). Questions of cultural identity. Sage.

The Daily Telegraph. (1996, November 23). On the Death of Idries Shah. Retrieved May 15, 2013, from Dorislessing.org: http://www.dorislessing.org/on.html

Waterman, D. (2002, October 9). The Space of Belonging: Alienation in Doris Lessing's The Marriages between Zones Three, Four and Five. Retrieved May 14, 2013, from Durham University Websie: http://www.dur.ac.uk/postgraduate.english/waterman.htm 